\title{
Kinetics of the Removal of Hydrogen Chloride Gas Using Hydroxysodalite at High Temperatures
}

\author{
Takaaki Wajima
}

\begin{abstract}
Hydrogen chloride (HCl) is an acidic pollutant that is present in the flue gases of most municipal and hazardous waste incinerators. It is important to treat gaseous $\mathrm{HCl}$ in incineration streams efficiently to avoid adverse environmental consequences. The removal of hydrogen chloride gas using hydroxysodalite $\left(\mathrm{Na}_{8} \mathrm{Al}_{6} \mathrm{Si}_{6} \mathrm{O}_{24}(\mathrm{OH})_{2}\right)$ at high temperatures $\left(600-900{ }^{\circ} \mathrm{C}\right)$ using a fixed-bed flow-type reactor was investigated in this study. $\mathrm{HCl}$ was efficiently removed from $\mathrm{N}_{2}$ containing 1000-ppmv $\mathrm{HCl}$ with a reaction time of $2 \mathrm{~h}$ at high temperatures. The hydroxysodalite reacted efficiently with the $\mathrm{HCl}$ gas at temperatures between 600 and $800{ }^{\circ} \mathrm{C}$, and was transformed into sodalite $\left(\mathrm{Na}_{8} \mathrm{Al}_{6} \mathrm{Si}_{6} \mathrm{O}_{24} \mathrm{Cl}_{2}\right)$. The amount of $\mathrm{HCl}$ fixed increased as the temperature increased to $800{ }^{\circ} \mathrm{C}$ but decreased when the temperature was increased to $900{ }^{\circ} \mathrm{C}$ because some of the hydroxysodalite and sodalite was transformed into nepheline $\left(\mathrm{NaAISiO}_{4}\right)$. The most chlorine was fixed at $800{ }^{\circ} \mathrm{C}$ (the amount fixed was $56 \mathrm{mg} / \mathrm{g}$ ). The reaction kinetics were assessed, and the pseudo-first-order and pseudo-second-order rate constants were calculated. Removal experiments showed that the removal process followed pseudo-second-order kinetics rather than pseudo-first-order kinetics. Increasing the temperature of the fixed-bed reactor to $800{ }^{\circ} \mathrm{C}$ increased the amount of $\mathrm{HCl}$ that was removed while keeping the removal kinetics almost the same.
\end{abstract}

Index Terms-Gaseous $\mathrm{HCl}, \mathrm{HCl}$ removal, high temperature, hydroxysodalite, reaction kinetics.

\section{INTRODUCTION}

Incineration may be the most environmentally sound way of disposing of hazardous waste. However, certain difficulties are associated with incineration, including the need to remove air pollutants, such as hydrogen chloride $(\mathrm{HCl})$, sulfur oxides, nitrogen oxides, and other contaminants, from the waste gases produced.

The high solubility and corrosive nature of $\mathrm{HCl}$ gas make it one of the most troublesome acidic gases even though it is not emitted into the environment in particularly large quantities. $\mathrm{HCl}$ must be removed from flue gases before the flue gases are emitted to the atmosphere. The combustion of municipal and hazardous waste is a major source of $\mathrm{HCl}$ to the environment. $\mathrm{HCl}$ gas emitted from incinerators is mainly produced through the destruction of toxic halogenated organic waste, including pesticides, chlorinated hydrocarbons (such as polyvinyl chloride in solid waste), and polychlorinated biphenyls in industrial waste [1].

In Japan, $\mathrm{HCl}$ gas generated when incinerating municipal

Manuscript received June 10, 2015; revised September 22, 2015. This work was supported in part by an ISIJ Research Promotion Grant.

Takaaki Wajima is with the Department of Urban Environment Systems, Graduate School of Engineering, Chiba University, Japan (e-mail: wajima@ tu.chiba-u.ac.jp). waste is treated by blowing $\mathrm{Ca}(\mathrm{OH})_{2}$ powder into the exhaust gas, converting $\mathrm{HCl}$ into $\mathrm{CaCl}_{2}$. The $\mathrm{CaCl}_{2}$ is then collected as fly ash and disposed of in landfill sites. The currently used scrubber techniques for removing $\mathrm{HCl}$ at low temperatures (below $300{ }^{\circ} \mathrm{C}$ ) are relatively simple, easy to operate, and have low capital costs [2]-[4]. However, $\mathrm{CaCl}_{2}$ is very soluble, and can be leached from ash in landfill sites and released into the aquatic environment. To prevent the environmental damage this would cause, the leachate is treated with $\mathrm{Na}_{2} \mathrm{CO}_{3}$ to convert the $\mathrm{Ca}^{2+}$ into insoluble $\mathrm{CaCO}_{3}$, and the leachate is then diluted with water to decrease the $\mathrm{Cl}^{-}$concentration. This method requires a considerable amount of water, and the lifetimes of available landfill sites are decreased because of the amount of fly ash that is disposed of. It is therefore necessary to develop new methods for treating gaseous $\mathrm{HCl}$ produced in incinerators.

Sodalite is a microporous crystallized aluminosilicate in zeolite group minerals, and was first synthesized by Pauling in 1930 [5]. Hydroxysodalite $\left(\mathrm{Na}_{8} \mathrm{Al}_{6} \mathrm{Si}_{6} \mathrm{O}_{24}(\mathrm{OH})_{2}\right)$ is member of the sodalite mineral group, and is a major product of the hydration of calcium aluminate cement. Its structure consists of a framework of 4- and 6- membered rings of $\mathrm{SiO}_{4}$ and $\mathrm{AlO}_{4}$ tetrahedra, and the $\mathrm{Si}: \mathrm{Al}$ ratio equals $1: 1$, which is the lowest possible ratio for zeolite group minerals. There are many reports for the synthesis of hydroxysodalite from various raw materials, such as coal fly ash [6]-[13], paper sludge ash [14-[23], oil shale ash [24], [25], waste sandstone cake [26]-[29], natural kaolinite [30], metakaolin [31], expanded perlite [32], waste porcelain [33], natural clinker [34], thermally treated sediment [35] and so on.

Hydroxysodalite has recently been proposed as an adsorbent of hydrogen chloride from high-temperature incinerator exhaust gases. It has been found that hydroxysodalite can be very useful for fixing $\mathrm{HCl}$ gas at $150-600{ }^{\circ} \mathrm{C}$ [36]. However, little information is available on the kinetics of $\mathrm{HCl}$ removal by hydroxysodalite at temperatures of $600-900{ }^{\circ} \mathrm{C}$, which are the temperatures that incinerator furnaces typically work at.

The aim of this study was to develop a new and efficient method for removing $\mathrm{HCl}$ gas from flue gases at high temperatures using hydroxysodalite. $\mathrm{HCl}$ removal from $\mathrm{N}_{2}$ containing 1000-ppmv $\mathrm{HCl}$ gas was studied using a fixed-bed reactor at $600-900{ }^{\circ} \mathrm{C}$. The experiments were mainly performed to investigate the kinetics of $\mathrm{HCl}$ removal using the experimental system.

\section{MATERIALS AND METHODS}

\section{A. Hydroxysodalite Sample}

Hydroxysodalite was synthesized in a stirred suspension, as 
described by Kato et al. [37]. Sodium silicate (55.6 g), sodium aluminate $(54.6 \mathrm{~g})$, and sodium hydroxide $(253.8 \mathrm{~g})$ were added to $1 \mathrm{~L}$ of distilled water, and the mixture was stirred with a magnetic stirrer at $90{ }^{\circ} \mathrm{C}$ for $8 \mathrm{~h}$. The mixture was then filtered to separate the solid product, and the product was dried at $80{ }^{\circ} \mathrm{C}$ in an oven overnight to give the hydroxysodalite that was used in the experiments. The morphology of the hydroxysodalite sample is shown in Fig. 1.

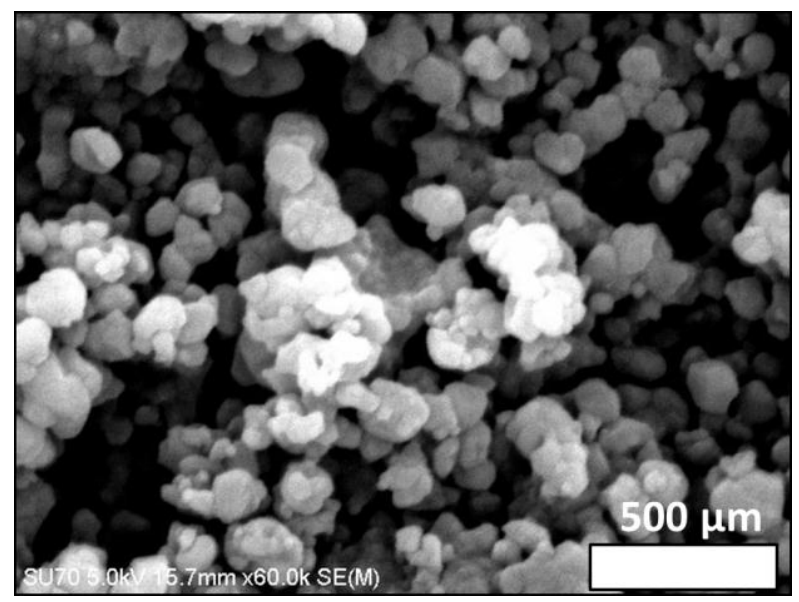

Fig. 1. Photograph of the hydroxysodalite sample.

\section{B. Fixation of $\mathrm{HCl} \mathrm{Gas}$}

The experiments in which $\mathrm{HCl}$ gas was fixed using hydroxysodalite at high temperatures were performed in a vertical reactor, shown schematically in Fig. 2. The reactor was a fused silica tube (17 mm i.d., 1-m long). The reactor was surrounded by an electric furnace to control its temperature. The sample was placed in the reactor, then $\mathrm{N}_{2}$ was passed through the reactor at $1 \mathrm{~L} / \mathrm{min}$ (the volume being measured at NTP) to replace the atmosphere in the reactor with $\mathrm{N}_{2}$. The reactor was then heated to the selected temperature (between 600 and $900{ }^{\circ} \mathrm{C}$ ) with $\mathrm{N}_{2}$ flowing through it at $1 \mathrm{~L} / \mathrm{min}$. Once the required temperature was reached, the reaction gas (1000-ppmv $\mathrm{HCl}$ in $\mathrm{N}_{2}$ ) was fed at $500 \mathrm{~mL} / \mathrm{min}$ into the fixed-bed reactor. $\mathrm{An} \mathrm{HCl}$ concentration of $1000 \mathrm{ppmv}$ is similar to the average concentration in incinerator exhaust gas in Japan. Each experiment was ended when the outlet $\mathrm{HCl}$ concentration reached $1000 \mathrm{ppmv}$. The gas exiting the reactor was periodically passed through distilled water in scrubbing bottles for $5 \mathrm{~min}$, which was enough time for all of the $\mathrm{HCl}$ in the gas to be dissolved. The $\mathrm{Cl}^{-}$concentrations in the solution from the scrubbing bottle samples were determined using an ion meter (TiN-5102; Toko Instruments, Tokyo, Japan) to allow the amount of $\mathrm{Cl}^{-}$ fixed by the hydroxysodalite to be determined. The $\mathrm{HCl}$ feed gas was stopped at the end of the experiment, and $\mathrm{N}_{2}$ was fed into the reactor until the reactor had cooled to room temperature. The solid sample in the reactor was then collected. The mineralogical composition of each solid sample was determined using an UltimaVI X-ray diffractometer (Rigaku, Tokyo, Japan). The $\mathrm{Cl}^{-}$content of each solid sample that had been used in an $\mathrm{HCl}$ removal experiment was also determined. A $0.1-\mathrm{g}$ aliquot of a sample was added to $10 \mathrm{~mL}$ of $0.1 \mathrm{M} \mathrm{HNO}_{3(\mathrm{aq})}$ in a 50 -mL centrifuge tube, then the tube was shaken using a reciprocal shaker for 6 h. The tube was then centrifuged for $10 \mathrm{~min}$, and the $\mathrm{Cl}^{-}$ concentration in the supernatant was determined to allow the $\mathrm{Cl}^{-}$content of the solid sample to be calculated.

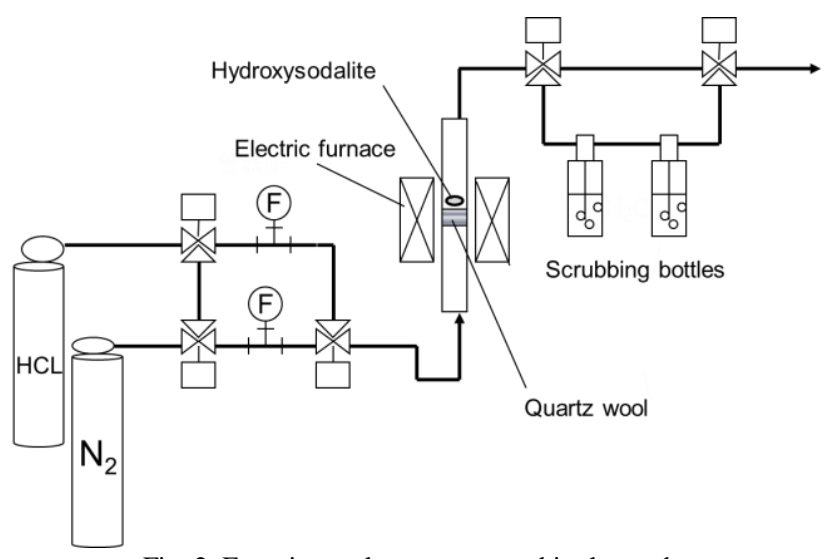

Fig. 2. Experimental apparatus used in the study.

\section{RESULTS AND DISCUSSION}

The removal of $\mathrm{HCl}$ in a hot gas stream by hydroxysodalite in a fixed-bed reactor was investigated. The amounts of $\mathrm{Cl}^{-}$ fixed by hydroxysodalite at different temperatures are shown in Fig. 3. Increasing the temperature from 600 to $800{ }^{\circ} \mathrm{C}$ increased the amount of $\mathrm{Cl}^{-}$fixed by the hydroxysodalite from 49.3 to $56.5 \mathrm{mg} / \mathrm{g}$, but the amount of $\mathrm{Cl}^{-}$fixed decreased to $44.3 \mathrm{mg} / \mathrm{g}$ when the temperature was increased to $900{ }^{\circ} \mathrm{C}$.

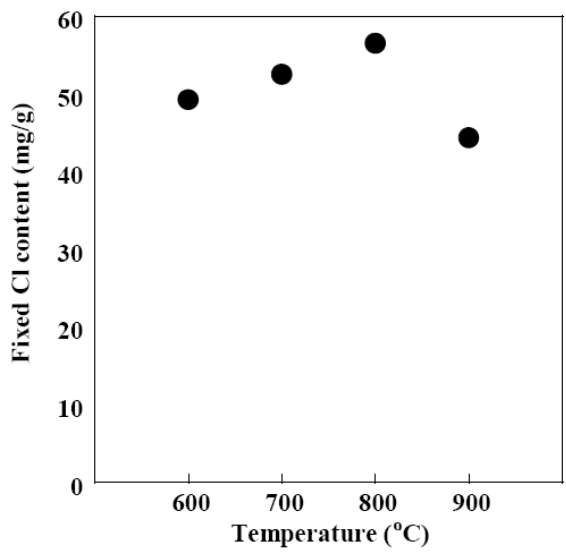

Fig. 3. Fixed $\mathrm{Cl}^{-}$contents in the solid samples after experiments at different temperatures.

The X-ray diffraction patterns of the hydroxysodalite before and after reacting with $\mathrm{HCl}$ gas at between 600 and $900{ }^{\circ} \mathrm{C}$ are shown in Fig. 4. The hydroxysodalite $\left(\mathrm{Na}_{8} \mathrm{Al}_{6} \mathrm{Si}_{6} \mathrm{O}_{24}(\mathrm{OH})_{2}\right)$ was transformed into sodalite $\left(\mathrm{Na}_{8} \mathrm{Al}_{6} \mathrm{Si}_{6} \mathrm{O}_{24} \mathrm{Cl}_{2}\right)$ when exposed to $\mathrm{HCl}$ at $600-800{ }^{\circ} \mathrm{C}$, but nepheline $\left(\mathrm{NaAlSiO}_{4}\right)$ was produced when the hydroxysodalite was exposed to $\mathrm{HCl}$ at $900{ }^{\circ} \mathrm{C}$. The $\mathrm{HCl}$ gas was efficiently removed to form sodalite at $600-800{ }^{\circ} \mathrm{C}$ through the reaction shown in (1).

$$
\mathrm{Na}_{8} \mathrm{Al}_{6} \mathrm{Si}_{6} \mathrm{O}_{24}(\mathrm{OH})_{2}+\mathrm{HCl} \rightarrow \mathrm{Na}_{8} \mathrm{Al}_{6} \mathrm{Si}_{6} \mathrm{O}_{24} \mathrm{Cl}_{2}+2 \mathrm{H}_{2} \mathrm{O}
$$

The hydroxysodalite and sodalite were transformed into nepheline at $900{ }^{\circ} \mathrm{C}$ through the reactions shown in (2) and (3).

$$
\mathrm{Na}_{8} \mathrm{Al}_{6} \mathrm{Si}_{6} \mathrm{O}_{24}(\mathrm{OH})_{2} \rightarrow 6 \mathrm{NaAlSiO}_{4}+2 \mathrm{NaOH}
$$




$$
\mathrm{Na}_{8} \mathrm{Al}_{6} \mathrm{Si}_{6} \mathrm{O}_{24} \mathrm{Cl}_{2} \rightarrow 6 \mathrm{NaAlSiO}_{4}+2 \mathrm{NaCl}
$$

The nepheline did not react with $\mathrm{HCl}$, so less $\mathrm{Cl}^{-}$was fixed at $900{ }^{\circ} \mathrm{C}$ than at lower temperatures because of the formation of nepheline.

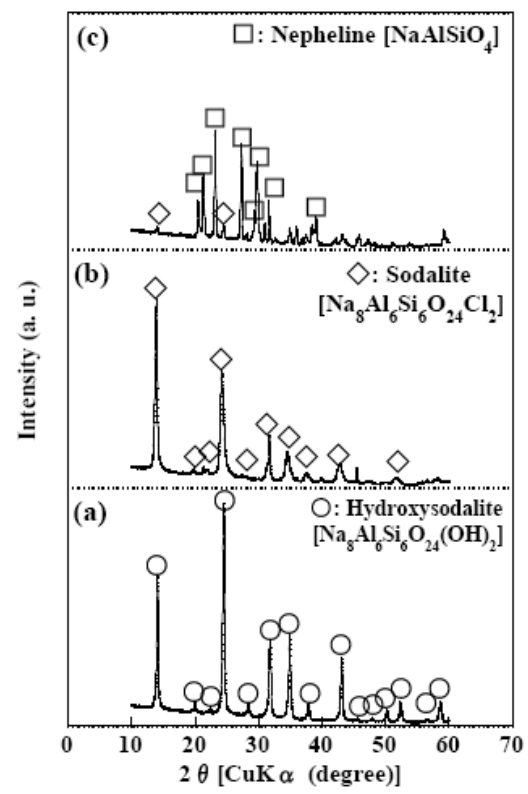

Fig. 4. X-ray diffraction patterns of (a) the raw hydroxysodalite sample, (b) the sample after an experiment at $700{ }^{\circ} \mathrm{C}$ had been performed, and (c) the sample after an experiment at $900{ }^{\circ} \mathrm{C}$ had been performed.

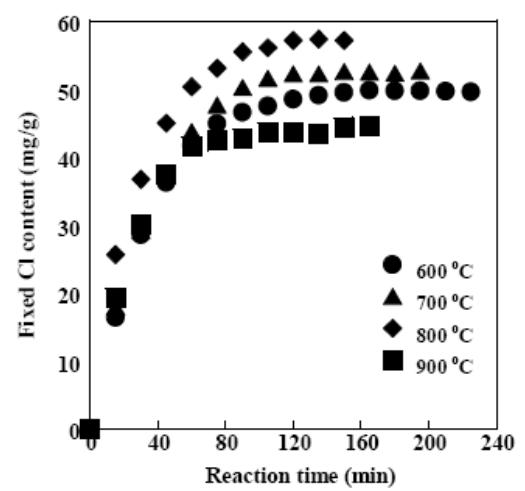

Fig. 5. Fixed $\mathrm{Cl}^{-}$contents in the samples over time during experiments at different temperatures.

The amounts of $\mathrm{Cl}^{-}$fixed by hydroxysodalite at temperatures between 600 and $900{ }^{\circ} \mathrm{C}$ as a function of the reaction time are shown in Fig. 5. It can be seen that the removal rate was high in the first $60 \mathrm{~min}$, then lower until equilibrium was reached. Increasing the reaction temperature to $800{ }^{\circ} \mathrm{C}$ increased the amount of $\mathrm{Cl}^{-}$that was fixed by the hydroxysodalite, but the amount of $\mathrm{Cl}^{-}$fixed decreased when the temperature was increased to $900{ }^{\circ} \mathrm{C}$.

The experimental kinetic data were fitted using a pseudo-first-order kinetic model [38] and a pseudo-second-order kinetic model [39], shown in (4) and (5), respectively,

$$
\begin{gathered}
\ln \left(q_{e}-q_{t}\right)=\ln q_{e}-k_{1} t, \\
\frac{t}{q_{t}}=\frac{1}{k_{2} \bullet q_{e}{ }^{2}}+\frac{1}{q_{e}} t,
\end{gathered}
$$

where $k_{1}\left(\min ^{-1}\right)$ and $k_{2}\left(\min ^{-1}\right)$ are the first order and second order rate constants, respectively. Equations (4) and (5) were applied for times between $t=0$ and $t=t_{e}$ (the equilibration time, which was usually different for the different systems). $q_{e}$ $(\mathrm{mg} / \mathrm{g})$ is the amount of $\mathrm{Cl}^{-}$fixed at $t_{e}$. The values of $k_{1}, k_{2}, R^{2}$ (the linear correlation coefficient), and $q_{e}$ (i.e., $q_{e, 1}$ and $q_{e, 2}$ ) are shown in Table I.

The $R^{2}$ values showed that, regardless of the temperature, the experimental data fitted the pseudo-second-order model much better than the pseudo-first-order model, indicating that the fixation process was second order.

The $q_{e, 2}$ values were $56.5,62.1,67.1$, and $49.8 \mathrm{mg} / \mathrm{g}$ at 600 , 700,800 , and $900{ }^{\circ} \mathrm{C}$, respectively. These values agreed well with experimental values obtained at $t_{e}(49.3,52.5,56.5$, and $44.3 \mathrm{mg} / \mathrm{g}$ at $600,700,800$, and $900{ }^{\circ} \mathrm{C}$, respectively). The $k_{2}$ values for between 600 and $800{ }^{\circ} \mathrm{C}$ were between 570 and 720 $\min ^{-1}$, meaning that the hydroxysodalite to sodalite reaction rates were almost the same at between 600 and $800{ }^{\circ} \mathrm{C}$ under the experimental conditions we used.

TABLE I: PARAMETERS FOR THE FIXATION OF HYDROGEN CHLORIDE GAS BY HYDROXYSODALITE

\begin{tabular}{ccccccc}
\hline \hline \multirow{2}{*}{$\begin{array}{c}\text { Temperature } \\
\left({ }^{\circ} \mathrm{C}\right)\end{array}$} & \multicolumn{3}{c}{$\begin{array}{c}\text { Pseudo-first-order } \\
\text { kinetics model }\end{array}$} & \multicolumn{3}{c}{$\begin{array}{c}\text { Pseudo-second-order } \\
\text { kinetics model }\end{array}$} \\
\cline { 2 - 7 } & $\begin{array}{c}q_{e, 1} \\
(\mathrm{mg} / \mathrm{g})\end{array}$ & $\begin{array}{c}k_{1} \\
(1 / \mathrm{min})\end{array}$ & $R^{2}$ & $\begin{array}{c}q_{e, 2} \\
(\mathrm{mg} / \mathrm{g})\end{array}$ & $\begin{array}{c}k_{2} \\
(1 / \mathrm{min})\end{array}$ & $R^{2}$ \\
\hline 600 & 26.1 & 7600 & 0.782 & 56.5 & 720 & 0.994 \\
700 & 33.2 & 8100 & 0.789 & 62.1 & 570 & 0.991 \\
800 & 37.2 & 10600 & 0.880 & 67.1 & 680 & 0.997 \\
900 & 21.6 & 10200 & 0.781 & 49.8 & 1180 & 0.995 \\
\hline \hline
\end{tabular}

\section{CONCLUSION}

Gaseous $\mathrm{HCl}$ was removed from a stream of gas using a fixed-bed reactor containing hydroxysodalite at high temperatures, between 600 and $900{ }^{\circ} \mathrm{C}$, which are almost the same temperatures as those that occur in practice in incinerator furnaces. The conclusions below were drawn.

1) Hydroxysodalite in a fixed-bed reactor can decrease $\mathrm{HCl}$ gas concentrations at high temperatures.

2) At below $800^{\circ} \mathrm{C}$ hydroxysodalite reacts with $\mathrm{HCl}$ to form sodalite, removing $\mathrm{HCl}$ gas, but above $900{ }^{\circ} \mathrm{C}$ hydroxysodalite forms nepheline, which does not remove $\mathrm{HCl}$ gas.

3) The fixation of $\mathrm{Cl}^{-}$by hydroxysodalite follows the pseudo-second-order kinetics model rather than the pseudo-first-order kinetics model.

4) The amount of $\mathrm{Cl}^{-}$fixed increases as the temperature increased to $800{ }^{\circ} \mathrm{C}$, and the fixation reaction rate remains almost the same between 600 and $800{ }^{\circ} \mathrm{C}$.

Our results suggest that hydroxysodalite could be used to remove $\mathrm{HCl}$ gas from effluent gases at high temperatures.

\section{ACKNOWLEDGMENT}

This work was supported in part by an ISIJ Research Promotion Grant.

\section{REFERENCES}

[1] B. K. Gullett, "Reduction of chlorinated organics in the incineration of wastes," U.S. Patent 5021 229, June 4, 1991. 
[2] M. Daoudi and J. K. Walters, "The reaction of $\mathrm{HCl}$ gas with calcined commercial limestone particles: The effect of particle size," Chem. Eng. J., vol. 47, pp. 11-16, Sept. 1991.

[3] G. Mura and A. Lallai, "On the kinetics of dry reaction between calcium oxide and gas hydrochloric acid," Chem. Eng. Sci., vol. 47, pp. 2407-2411, June 1992.

[4] C. E. Weinell, P. I. Jensen, K. Dam-Johansen, and H. Livbjerg, "Hydrogen chloride reaction with lime and limestone: kinetics and sorption capacity," Ind. Eng. Chem. Res., vol. 31, pp. 164-171, Jan. 1992.

[5] L. Pauling, "The structure of sodalite and helvite," Z. Kristallogr., vol. 74, pp. 213-225, 1930.

[6] N. Shigemoto, H. Hayashi, and K. Miyata, "Selective formation of Na-X zeolite from coal fly ash by fusion with sodium hydroxide prior to hydrothermal reaction," J. Mater. Sci., vol. 28, pp. 4781-4786, 1993.

[7] A. Singer and V. Berkgaut, "Cation exchange properties of hydrothermal treated coal fly ash,” Environ. Sci. Technol., vol. 29, pp. 1748-1753, 1995.

[8] X. Querol, A. Alastuey, A. López-Soler, and F. Plana, "A fast method for recycling fly ash: microwave-assisted zeolite synthesis," Environ. Sci. Technol., vol. 31, pp. 2527-2533, 1997.

[9] X. Querol, N. Moreno, J. C. Umaña, A. Alastuey, E. Hernández, A. López-Soler, and F. Plana, "Synthesis of zeolites from coal fly ash: An overview," Int. J. Coal Geol., vol. 50, pp. 413-423, 2002.

[10] K. Fukui, K. kanayama, T. Yamamoto, and H. Yoshida, "Effects of microwave irradiation on the crystalline phase of zeolite synthesized from fly ash by hydrothermal treatment," Adv. Powder Technol., vol. 18, pp. 381-393, 2007.

[11] H. Tanaka, A. Fujii, S. Fujimoto, and Y. Tanaka, "Microwave-assisted two-step process for the synthesis of a single-phase Na-A zeolite from coal fly ash," Adv. Powder Technol., vol. 19, pp. 83-94, 2008.

[12] C. A. Ríos, C. D. Williams, and C. L. Roberts, "A comparative study of two methods for the synthesis of fly ash-based sodium and potassium type zeolites," Fuel, vol. 88, pp. 1403-1416, 2009

[13] Y. Yu, X. Li, X. Zou, and X. Zhu, "Effect of seawater salinity on the synthesis of zeolite from coal fly ash," Front. Environ. Sci. Eng., vol. 8 , pp. 54-61, 2014.

[14] T. Wajima, K. Kuzawa, H. Ishimoto, O. Tamada, and T. Nishiyama, "The synthesis of zeolite-P, linde type A, and hydroxysodalite zeolites from paper sludge ash at low temperature $\left(80{ }^{\circ} \mathrm{C}\right)$ : Optimal ash-leaching condition for zeolite synthesis," Am. Miner., vol. 89, pp. 1694-1700, Nov.-Dec. 2004.

[15] T. Wajima, M. Haga, K. Kuzawa, H. Ishimoto, O. Tamada, K. Ito, T. Nishiyama, R. T. Downs, and J. F. Rakovan, "Zeolite synthesis from paper sludge ash at low temperature $\left(90^{\circ} \mathrm{C}\right)$ with addition of diatomite," J. Hazard. Mater., vol. 132, pp. 244-252, May 2006.

[16] T. Wajima, T. Shimizu, and Y. Ikegami, "Synthesis of zeolites from paper sludge ash and their ability to simultaneously remove $\mathrm{NH}_{4}{ }^{+}$and $\mathrm{PO}_{4}{ }^{3-}$," J. Environ. Sci. Health A, vol. 42, pp. 345-350, Feb. 2007.

[17] T. Wajima, H. Ishimoto, K. Kuzawa, K. Ito, O. Tamada, M. E. Gunter, and J. F. Rakovan, "Material conversion from paper-sludge ash in $\mathrm{NaOH}, \mathrm{KOH}$, and LiOH solutions," Am. Miner., vol. 92, pp. 1105-1111, Jul. 2007.

[18] T. Wajima and Y. Ikegami, "Zeolite synthesis from paper sludge ash via acid leaching," Chem. Eng. Comm., vol. 195, pp. 305-315, 2008.

[19] T. Wajima, T. Shimizu, and Y. Ikegami, "Zeolite synthesis from paper sludge ash with addition of diatomite," J. Chem. Technol. Biotechnol., vol. 83, pp. 921-927, Jun. 2008.

[20] T. Wajima and K. Munakata, "Material conversion from paper sludge ash in $\mathrm{NaOH}$ solution to synthesize adsorbent for removal of $\mathrm{Pb}^{2+}$, $\mathrm{NH}_{4}{ }^{+}$and $\mathrm{PO}_{4}{ }^{3-}$ from aqueous solution," J. Environ. Sci., vol. 23, pp. 718-724, 2011.

[21] T. Wajima and K. Munakata, "Synthesis of zeolitic material from paper sludge ash using diatomite," Mater. Trans., vol. 53, pp. 592-596, Apr. 2012.

[22] T. Wajima and K. Munakata, "Effect of alkali species on synthesis of K-F zeolitic materials from paper sludge ash for soil amendment," Chem. Eng. J., vol. 207, pp. 906-912, Oct. 2012.
[23] T. Wajima and K. munakata, "Removal of Ca from paper sludge ash by acid leaching and synthesis of high cation exchange capacity zeolite material," Int. J. Soc. Mater. Eng. Resour., vol. 18, pp. 7-10, Jun. 2011.

[24] N. R. C. F. Machado and D. M. M. Miotto, "Synthesis of Na-A and -X zeolites from oil shale ash," Fuel, vol. 84, pp. 2289-2294, Dec. 2005.

[25] T. Hu, J. S. Qiu, Y. Wang, C. Y. Wang, R. H. Liu, and C. G. Meng, "Synthesis of low $\mathrm{Si} / \mathrm{Al}$ ratio hydroxysodalite from oil shale ash without pretreatment," J. Chem. Technol. Biotechnol., vol. 90, pp. 208-212, Jan. 2015.

[26] T. Wajima, K. Yoshizuka, T. Hirai, and Y. Ikegami, "Synthesis of zeolite X from waste sandstone cake using alkali fusion method," Mater. Trans., vol. 49, pp. 612-618, Mar. 2008.

[27] T. Wajima, K. Munakata, and Y. Ikegami, "Conversion of waste sandstone cake into crystalline zeolite X using alkali fusion," Mater. Trans., vol. 51, pp. 849-854, May 2010.

[28] T. Wajima and K. Munakata, "Material conversion from waste sandstone cake into cation exchanger using alkali fusion," Ceram. Int., vol. 38, pp. 1741-1744, 2012.

[29] T. Wajima and Y. Ikegami, "Effect of chelating agent on the synthesis of zeolitc materials from waste sandstone cake using alkali fusion," ARS Separatoria ACTA, vol. 5, pp. 76-87, 2007.

[30] A. Gualtieri, P. Norby, G. Artioli, and J. Hanson, "Kinetic study of hydroxysodalite formation from natural kaolinites by time-resolved synchrotron powder diffraction," Microporous Mater., vol. 9, pp. 189-201, 1997.

[31] D. Novembre, B. D. Sabatino, D. Gimeno, and C. Pace, "Synthesis and characterization of $\mathrm{Na}-\mathrm{X}, \mathrm{Na}-\mathrm{A}$ and $\mathrm{Na}-\mathrm{P}$ zeolites and hydroxysodalite from metakaolinite," Clay Miner., vol. 46, pp. 339-354, 2011.

[32] M. Król, W. Mozgawa, J. Morawska, and W. Pichór, "Spectroscopic investigation of hydrothermally synthesized zeolites from expanded perlite," Microporous Mesoporous Mater., vol. 196, pp. 216-222, 2014.

[33] T. Wajima and Y. Ikegami, "Synthesis of zeolitic materials from waste porcelain at low temperature via a two-step alkali conversion," Ceram. Int., vol. 33, pp. 1269-1274, 2007.

[34] C. A. Ríos and C. D. Williams, "Synthesis of zeolitic materials from natural clinker: A new alternative for recycling coal combustion by-products," Fuel, vol. 87, pp. 2482-2492, Sep. 2008.

[35] D. Y. Wu, Y. K. Lu, H. N. Kong, C. Ye, and X. C. Jin, "Synthesis of zeolite from thermally treated sediment," Ind. Eng. Chem. Res., vol. 47, pp. 295-302, Jan. 2008.

[36] Y. Shibazaki, K. Suzuki, and Y. Noguchi, "Synthesis of hydroxysodalite from diatomaceous earth," Japan Patent H10-55738, Aug. 31, 1999

[37] Y. Kato, K. Kakimoto, H. Ogawa, M. Tomari, and E. Sakamoto, "Application of hydrothermal crystallized coal ashes to waste water treatment I," Kougyo Yousui, vol. 331, pp. 27-33, 1986

[38] Y. S. Ho, "Citation review of Lagergren kinetic rate equation on adsorption reactions," Scientometrics, vol. 59, 171-177, Jan. 2004.

[39] Y. S. Ho, and G. McKey, "Pseudo-second order model for sorption processes," Process Biochem., vol. 34, pp. 451-465, July 1999.

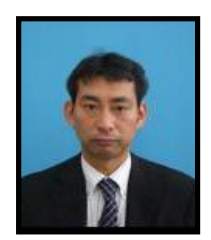

Takaaki Wajima was born in February 1976 in Saga Prefecture, Japan. He has been Associate Professor in the Department of Urban Environment Systems, Graduate School of Engineering, Chiba University, Japan, since 2013. He received his bachelor's degree and master's degree in resource engineering from Kyoto University, Japan, in 1998 and 2000, respectively, and his Ph.D in environmental mineralogy and technology from Kyoto University, Japan, in 2004. His main $\mathrm{PhD}$ research theme was "micro-porous materials synthesized from paper sludge ash at low temperature, and its chemical mineralogy." In 2004, he moved to the Institute of Ocean Energy at Saga University to work as a postdoctoral researcher, and from 2007 to 2013 he was Assistant Professor at Akita University, Japan. His main research interests are waste recycling, resource recovery, and environmental purification. 